\title{
A Formation Method of Flexible Learning Objects
}

\author{
Ramūnas KUBILIŪNAS \\ Laboratory of Distance Learning Technologies, Kaunas University of Technology \\ Studentu 67-513, LT-51392 Kaunas, Lithuania \\ e-mail:ramunas.kubiliunas@ktu.lt
}

Eduardas BAREIŠA

Department of Software Engineering, Kaunas University of Technology Studentu 50-404, LT-51368 Kaunas, Lithuania

e-mail: eduardas.bareisa@ktu.lt

Received: July 2008

\begin{abstract}
A brief overview of formation method of flexible learning objects is presented in this article. The basis of this method is e-learning material that is structured and separated from display rules. The learning objects that have such e-learning material may be adapted to individual needs and may be used in different learning contexts without changing e-learning material. To change the presentation form of e-learning material of such objects, it is enough to change display rules of this material. However, if the e-learning material must be adapted too, it is much easier to do this as the material is structured and contains less technical information of representation. The adaptation of such learning objects is more effective and needs less work time input, therefore they are called as flexible learning objects.
\end{abstract}

Keywords: e-learning material, e-learning content, learning object, reusable learning object, reuse of learning object, flexible learning object.

\section{Introduction}

Distance learning is one of the widely used learning forms, which has already been started to legalize in higher education institutions. One of the most important elements in the process (in the preparation as well as in the delivery stages) of distance learning is learning material. In a very well developed infrastructure of information communications, which are based on information technologies, learning material is delivered in electronic format and is called as e-learning material. However, such material has its own requirements and not all formats are suitable. For instance, to prepare initial material in electronic format, computer software programs Microsoft Office Word, OpenOffice Writer or other similar text editors are usually used. Text documents are suitable for printing, storing and editing, but they are not suitable for delivering to learners by internet based learning content management systems (LCMS) and learning management systems (LMS), which are used in distance learning. Therefore, text documents are converted to Web pages or, in exceptional cases, e-learning material is prepared directly in a Web page format. 
Besides, learning material for distance learning sometimes must be delivered not only in a Web page format, but also in other formats that are suitable for printing or viewing with different, not only computer based tools. Therefore, text documents are converted to other formats too. However, it is not effective, because a few copies of the same learning material are created. In purpose to correct or renew the same learning material which was prepared in different electronic formats all copies of learning material must be changed. Consequently, more time is required to do this than it would be needed to change material only in one format. Whereas after the change of learning material only in the initial electronic format, material should be converted to the necessary formats repeatedly. Therefore, more time would be required too. Besides, material in distance learning in a Web page format must be divided into small parts, but it is impossible to do this with common text editors. Thus, even more time is required to convert material into Web pages.

There are many appropriate tools developed that let to prepare e-learning material in such a way that it could be viewed or converted to necessary formats automatically. It is best when such tools, differently from Web editors, let not only to convert material prepared in the initial format, but also to separate content of e-learning material from display rules. In such a case it is possible to change (to correct or renew) not only material, but also display or transformation rules without changing the program that displays or converts e-learning material. This increases the flexibility (the possibility to adapt material effectively for necessary learning context when material must be changed; or for learning situation when display or transformation rules must be changed) of prepared e-learning material.

However in such a case another problem comes. The e-learning material preparation tools (markup languages as well as programs) that allow to separate content of e-learning material from display rules, are developed by formalizing the structure of e-learning material and ones markup language with common, but not visual design methods that are being applied in software engineering. Whereas on purpose to change or design display or transformation rules of prepared e-learning material content, more time is required to find out the structure of initial e-learning material, especially for content experts. Therefore, to solve appropriate problem the visual design methods that are being applied in informatics engineering were suggested in this article for formalization of the structure of e-learning material.

One more problem that comes while preparing e-learning material is the use of prepared material. For instance, in a Web page format prepared or converted e-learning material is normally directly uploaded to LMS. However, this is not effective, because a content of material must be prepared with appropriate LMS tool when e-learning material was uploaded, as in a Web page format prepared material is usually divided into small parts. Especially this is relevant when prepared material must be corrected or renewed. The changed material must be converted again, if it has been changed in the initial format, and it must be uploaded to appropriate LMS where the content of material must be prepared again, if the structure of material has been changed. To solve this problem the structure of prepared e-learning material is described with commonly used distance learning standards and e-learning material is delivered as learning objects (LO), which 
already may be automatically uploaded to LMS that are compatible with these standards. Moreover, the $\mathrm{LO}$ are also used to share and reuse a learning content. Whereas to provide information (metdata) about the object an appropriate metadata standard is used.

However, using LO yet remains a problem of e-learning material format that are delivered as objects, because there is no appropriately developed standard, and a problem of LO formation. Usually before reusing LO, a learning material (basically the object oneself) that is delivered as LO must be adapted for necessary learning context when material must be changed or, for learning situation when display or transformation rules must be changed. But if the object is not adapted by the owner, he or she may have no e-learning material that is delivered as LO in the initial format. This means that more time may be required to correct the material, because it is possible that several and not necessarily effective programs must be used as compared with the programs that are being used and have been used for preparation of e-learning material in the initial format. Consequently, the flexibility (the possibility to adapt the object effectively for necessary learning context and situation when it may not be used directly so, like e-learning material is delivered by it) of LO is limited.

Besides, on purpose to form the $\mathrm{LO}$ the description of ones content and it self must be prepared. Such description may be automatically prepared by LO formation program. However, without e-learning material that is prepared in the initial format and on purpose to adapt the available $\mathrm{LO}$ when the structure of $\mathrm{LO}$ content must be changed too, it will be required more time to change the description of the object as it has be done not automatically. Finally, on purpose to design and develop programs for preparation of LO description automatically, the earlier mentioned problem to find out the structure of e-learning material comes up again. This problem comes up, if the e-content, that is delivered as LO, preparation tools that allow to separate content of e-learning material from display rules are being used.

The novelty and relevance of appropriate problems are fairly new. Therefore, the purpose of this article is to present a flexible learning objects (FLO) preparation method that increases the effectiveness of e-learning material preparation and delivery in different formats as well as increases the flexibility of LO, which are used to deliver such e-learning material, adaptation for individual requirements. In the first part of this article the results of analysis of requirements for e-learning material and LO are presented. In the second part of this article the formation method of FLO is presented. Finally, the conclusions of the research and analysis of the FLO are given in the third part of this article.

\section{E-Learning Material and Learning Objects}

On purpose to create the formation method of FLO the analysis of e-learning material and LO has been done. This analysis was necessary: to find out the requirements for e-learning material preparation and LO formation in distance learning process; to set the factors that increase the effectiveness of e-learning material preparation and use in different learning situations; and to set the evaluation criterions of e-learning material as 
well as tools for e-learning material preparation. The results of analysis allowed to find out best technologies for e-learning material preparation. The factors that increase the effectiveness of e-learning material preparation and use in different learning situations helped to design the formation method of FLO. The evaluation criterions have been used to evaluate the e-learning material preparation and $\mathrm{LO}$ formation tools (markup languages as well as programs) on purpose to find out the most suitable one for FLO formation method.

\subsection{E-Learning Material in Distance Learning Process}

In a previously published article, which was related to the topic of this article, the distance learning process has been analyzed (Targamadze et al., 2005). The main purpose of such analysis was to find out the place of e-material preparation in distance learning development. The analysis showed that one of the most important stages in distance learning development is preparation of distance learning course and e-learning material which is delivered in that course. Therefore, there are many tools that may be used to prepare such a course and e-learning material. Consequently many people ask which tool is the best. And Horton writes, that there is no one tool that could do everything and many tools must be used for successful project (Horton and Horton, 2003). To find out the main categories of these tools the brief analysis about distance learning participants and their roles in development of distance learning process has been done. Also the brief analysis about e-learning development tendencies has been done too. The analysis showed, that preparation of e-material must take the shape of integration like virtual learning environments took. Blažauskas et al. (2005) also prove such tendency: "On purpose that preparation of e-learning material would be successful, the e-learning material preparation environment must be integrated with tools for support and preparation of e-learning material (including tools designed for collaboration)" (Blažauskas et al., 2005). According to the analysis the conclusion is that e-learning material should be prepared in such a way, that it could be used and reused in different LMS.

\subsection{E-Learning Material}

As it was already mentioned, the e-learning material is one of the most important parts of distance learning. To prepare e-learning material the appropriate tools and technologies must be used. However, Anderson said that "the instructional strategy and not the technology influences the quality of learning" (Anderson and Elloumi, 2004). Consequently, the requirements for structure as well as for format of e-learning material have been analyzed before the analysis of tools and technologies. The analysis of requirements helped to set the evaluation criterions of e-learning material structure that could make the best instruction. These evaluation criterions were also used to evaluate the e-learning material preparation tools (markup languages as well as programs) on purpose to find out the most suitable one for FLO formation method.

First of all, the evaluation criterions according to online learning course have been set as the e-learning material is used in distance learning courses that are usually delivered 
Table 1

The evaluation criterions of e-learning material structure according to the requirements for common components of distance learning course

\begin{tabular}{|c|c|c|}
\hline No. & $\begin{array}{l}\text { Common component of distance } \\
\text { learning course/criterion }\end{array}$ & Possible realization in e-learning material \\
\hline 1. & $\begin{array}{l}\text { Course syllabus. The brief descrip- } \\
\text { tion of the course. }\end{array}$ & $\begin{array}{l}\text { Page with descriptions about the learning material and } \\
\text { requirements for successful learning. }\end{array}$ \\
\hline 2. & $\begin{array}{l}\text { Course orientation. The brief in- } \\
\text { formation about the teacher or au- } \\
\text { thor of the course, about specific in- } \\
\text { formation and instruction activities, } \\
\text { about course books references and } \\
\text { other resources. }\end{array}$ & $\begin{array}{l}\text { The special pages in e-learning material: } \\
\text { - the page about the author or teacher, } \\
\text { - the page with main course goals; } \\
\text { - the page with additional information; } \\
\text { - the page with learning references or literature list. }\end{array}$ \\
\hline 3. & $\begin{array}{l}\text { Course content. References to the } \\
\text { modules of course. Learning goals } \\
\text { in each lesson. }\end{array}$ & $\begin{array}{l}\text { The content page with links to separate parts of learn- } \\
\text { ing material. The learning goals in material pages. }\end{array}$ \\
\hline 4. & $\begin{array}{l}\text { Course calendar. The start and end } \\
\text { dates of each module. }\end{array}$ & $\begin{array}{l}\text { This information could be given in the page about the } \\
\text { material or directly in the learning material. }\end{array}$ \\
\hline 5. & $\begin{array}{l}\text { Site map. The alternative way of } \\
\text { navigating the course. }\end{array}$ & $\begin{array}{l}\text { This could be realized with particular material page } \\
\text { with links to parts of material or link to the content } \\
\text { page. }\end{array}$ \\
\hline 6. & $\begin{array}{l}\text { Index. The index references to all } \\
\text { material in alphabet order. }\end{array}$ & $\begin{array}{l}\text { This could be realized with automatic tools that col- } \\
\text { lect information directly from learning material. }\end{array}$ \\
\hline
\end{tabular}

through internet. Besides most authors maintain, that internet is effective mean to deliver distance learning courses as it ensures the fast exchange of information and high level of interactivity (Piskurich, 2004). The generalized evaluation criterions of e-learning material structure are given in the Table 1 . These evaluation criterions have been set according to the requirements for the common components of effective university distance learning course that have been defined by Howard (Howard et al., 2003).

The given evaluation criterions of the e-learning material structure are good for general structure of e-learning material. However, "Before any learning materials are developed, educators must, tacitly or explicitly, know the principles of learning and how students learn. This is especially true for online learning, where the instructor and the learner are separated. The development of effective online learning materials should be based on proven and sound learning theories" (Anderson and Elloumi, 2004). Therefore, the generalization more specific evaluation criterions of e-learning material structure are given in the Table 2. These evaluation criterions have been set according to the requirements of traditional schools (behaviorist (Anderson and Elloumi, 2004; Dietinger, 2003; Mishra and Sharma, 2005; Tomey, 2008), cognitive (Anderson and Elloumi, 2004; Carbonara, 2005; Tomey, 2008) and constructivist (Anderson and Elloumi, 2004; Carbonara, 2005; Dietinger, 2003; Mishra and Sharma, 2005; Tomey, 2008) schools of learning).

The defined requirements and evaluation criterions of e-learning material are very important as they are related with structure of material. However, to find out the best 
Table 2

The evaluation criterions of e-learning material structure according to the requirements for instruction by traditional instruction theories

\begin{tabular}{ccc}
\hline No. & $\begin{array}{c}\text { Requirements for instruction by instruction } \\
\text { theories/criterion }\end{array}$ & $\begin{array}{c}\text { Possible realization in e-learning } \\
\text { material }\end{array}$ \\
\hline
\end{tabular}

Requirements for instruction in behaviorist school

1. Learners should be told the explicit outcomes of the General goals and learning objectives. learning.

2. Learning materials must be sequenced appropriately Separate small parts of e-learning mateto promote learning. rial, but related with navigation links.

Requirements for instruction in cognitive school that are related to memory

3. Online instruction must use strategies stimulating the conception and attention:

a. Important information for reading should be placed Important information elements. in the center of the screen.

b. Information critical for learning should be highlighted to focus learners' attention.

c. Learners should be told why they should take the lesson.

Very important information elements.

Learning objectives for any part of e-learning material.

4. Strategies should be used to allow learners to retrieve existing information from long-term memory to help make sense of the new information:

a. Use pre-instructional questions to set expectations and to activate the learners' existing knowledge structure.

b. Information should be chunked to prevent overload during processing in working memory.

Learning objectives or separate material elements for additional information.

Separate small parts of e-learning material, but related with special links. The content of all e-learning material. Some parts may be not contented.

Requirements for instruction in cognitive school that are related to individuals

5. Information should be presented in different modes to accommodate individual differences in processing and to facilitate transfer to long-term memory. Where possible, textual, verbal, and visual information should be presented to encourage encoding.

6. Encourage learners to use their met cognitive skills to help in the learning process.
Possibility to use multimedia in elearning material, e.g., pictures, audio files, video files, interactive and other format multimedia elements.

Simple self test questions with links to answers in e-learning material.

Requirements for instruction in constructivist school

7. Learners should be given control of the learning process.

Free hierarchical as well as linear navigation in e-learning material.

8. Learning should be made meaningful for learners. The learning materials should include examples that relate to students, so that they can make sense of the information. Assignments and projects should allow learners to choose meaningful activities to help them Possibility to insert learning examples. However, it should be possible to insert them as separate learning material elements with links in material to them. apply and personalize the information. 
format of e-learning material the analysis of appropriate technologies has been done too. The analysis showed, that e-learning material should be prepared in a flexible format, that author or other users could display it in different designs or convert to different formats without changing the material. It is possible when content of e-learning material is structured and separated from display rules. On purpose to do this the XML as most suitable technology at the moment should be used (Bareiša et al., 2005). As this technology is discussed more than enough in literature the overview of it is skipped in this article. The XML allows to separate content of e-learning material from display rules and allows to change or design display or transformation rules. In such a way prepared e-learning material may be viewed with web browsers as it may be displayed in a Web pages format. This means that such e-learning material may be used in LMS. Also, such e-learning material may be converted to PDF format documents (PDF may be printed) as well as to other formats. This is very important too, as Moore and Anderson (2003) say, - "The printed material is and will stay most important technology for open and distance learning" (Moore and Anderson, 2003).

\subsection{Learning Objects}

To design the formation method of FLO, the analysis of requirements for LO has been done. "In order to be delivered to learners, LOs must first be analyzed, specified, and represented" (Štuikys and Damaševičius, 2008). The analysis showed, that the most important parts of LO are metadata and content package manifest that holds metadata of LO and structure of LO content package. The structure of common LO manifest is given in Fig. 1. Picture was developed according to the examples given in the literature (Dietinger,

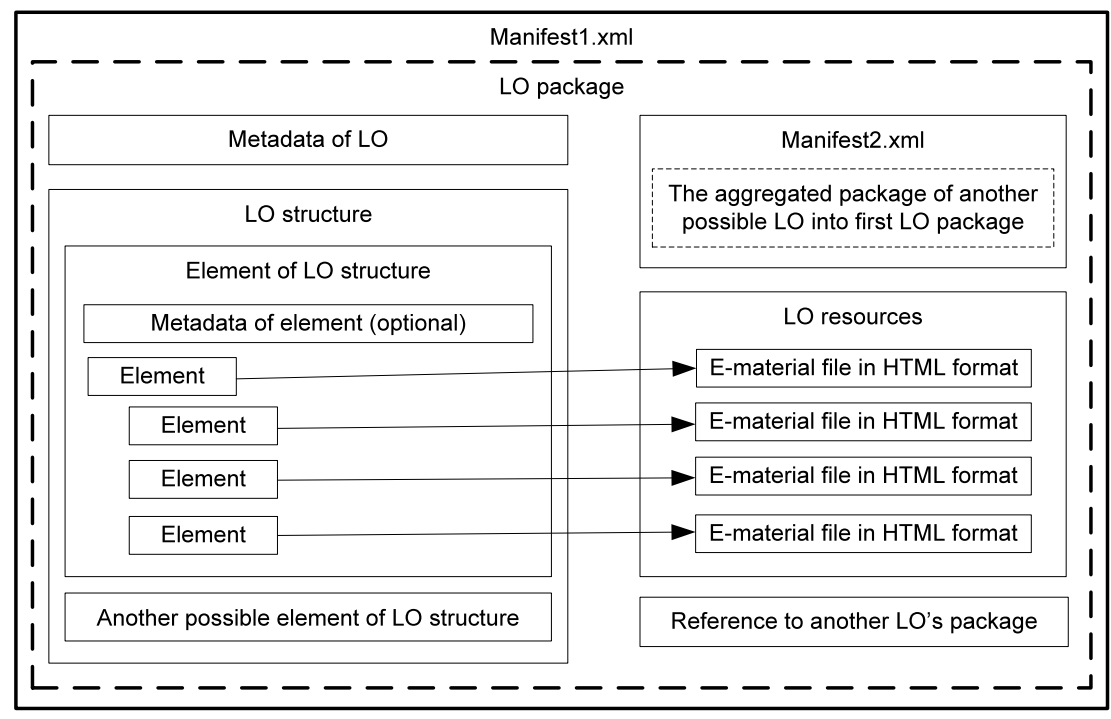

Fig. 1. Manifest of common LO content package. 
2003) and (Downes, 2000). According to the example of manifest, the e-learning material may be delivered as LO. Consequently, the elements (documents and multimedia files) of e-learning material should be described in the LO manifest. Whereas, to prepare such manifest also is used XML technology. Therefore, it is possible to convert information given in the XML based e-learning material to information that is necessary to manifest of LO content package. On purpose to shorten the term "e-learning material", it is named as "e-material" further in this and other pictures.

However, the analysis of LO showed that on purpose to prepare the LO manifest not only XML technology must be used, but also appropriate standards. There are several standards that are widely used in distance learning to describe the LO manifest. To describe the structure of object content package, IMS CP or SCORM standards may be used (Morrison, 2003). In such way formatted LO package could be uploaded automatically into different LMS that are compatible with these standards. To describe the metadata of LO that comes in the manifest too, the LOM standard may be used.

Independently from LO package structure the analysis of LO usage was done too. The analysis showed, that advantages of LO are its reusability. LO may be used and reused in different learning contexts and situations. However, according to Teege G. the more two requirements were defined for LO: they must be abstract enough and adjustable (Teege, 2002). Very rarely LO may be reused without changing the e-learning material that it is delivered as LO. Therefore, the conclusion is that LO must contain e-learning material in flexible format. As it was mentioned earlier, e-learning material should be prepared in XML based format. The requirements for such e-learning material and appropriate technologies were defined in the previous chapter.

\subsection{E-Learning Material Preparation Tools}

The earlier discussed preparation of e-learning material has two important aspects: an XML based markup language that must be used to prepare e-learning material and a tool that could be used to apply the markup language automatically. There are many appropriate markup languages and tools that could be used. On purpose to find out which would be the best, the several markup languages and software tools were analyzed and evaluated according to the criterions that were set in the analysis of structure of e-learning material and some other criterions that were set during analysis of tools. The results of the evaluation of markup languages are presented in the Table 3. On purpose to shorten the table there are given only that criterions which tools meet not identically. The evaluation of software tools is skipped as they are not most important part for idea of formation of flexible learning objects.

As it is shown in the Table 3, it were compared six e-learning material markup languages. They were selected as ones that are based XML technology and are designed for preparation of e-learning material. Most of them meet only half requirements and only two of them meet almost all requirements. The eLML could be better than CourseML (KTU), because it is open sourced. However, CourseML(KTU) has better software tool and more display designs. Thus, the conclusion is that CourseML (KTU) could be used as 
Table 3

The comparison of e-learning material markup languages

\begin{tabular}{lcccccc}
\hline Criterion / Title & CourseML(KTU) & CourseML (AOUKA.) & eLML & LMML & ML3 & TeachML \\
\hline Course syllabus & + & $+/-$ & + & + & + & + \\
Course orientation & + & + & + & + & + & + \\
Course content & + & & + & & + & \\
Learning outcomes & + & & + & & & \\
Information importance & + & + & + & + & + & + \\
Learning objectives & + & & + & & & - \\
Display designs & $+/ 220$ & & $+/ 2$ & $-/ 1$ & $+/ 1$ & $+/-/ 1$ \\
Controlled process & + & & + & + & + & + \\
Software tool & CDK & & Eclips & - & + & - \\
Simplicity & + & & $+/-$ & - & - & - \\
Development & + & & + & - & + & $+/-$ \\
\hline
\end{tabular}

basis for formation method of FLO. Nevertheless, neither CourseML (KTU) (Kubiliūnas et al., 2002) nor eLML (Fisler and Bleisch, 2006) have visual formal description that could be used to design the algorithms of formation method of flexible objects. Such description could help to find out the structure of e-learning material and prepare the display and transformation rules.

\section{The Formation Method of Flexible Learning Objects}

As it was defined in the previous chapter the e-learning material that will be delivered as LO must be structured. The content of e-learning material must be separated from display rules. Moreover, the e-learning material must be described with appropriate standards on purpose it could be named and used as LO. In such a way formatted LO would be more flexible nor common LO, because it would be possible to adapt the object for necessary learning context and situation more effective. To form such objects the formation method of FLO has been designed. Whereas designing of the method was started from the formalization of structure of e-learning material. This was required on purpose to create formation algorithms of formation method of LO. The main novelty of this method is that FLO contains e-learning material in XML format unlike usual widely used LO.

\subsection{The Structure of E-Learning Material and Markup Language}

To prepare the formal description of e-learning material structure and appropriate CourseML markup language the abstract definition of e-learning material and all elements that are used in markup language have been done. The abstract description have been used as basis for formal description and have been used to validate the structure of e-learning material according to the evaluation criterions that were set in the previous chapter. However the abstract description is useful only to validate language elements, 
but not for designing the XML schema of markup language or material transformations to other formats.

As it was mentioned earlier, to formalize the structure of e-learning material and its markup language the visual design methods should be used. For the very visual description it could be used the design pattern class diagram. The elements of markup language would be classes and attributes of elements would be methods of classes. The relationships between classes would show the structure of e-learning material. The model of e-learning material markup language and main element Page is given in Fig. 2. The other models of data elements are developed too, but skipped in this article as the purpose of it is the brief overview of the formation method of FLO.

However, even visual models are better for presentation of structure of e-learning material than strict formal descriptions, to describe material formally that all the symbols (non terminal as well as terminal) could be included into description the formal method is needed yet. Therefore the regular tree grammar could be used and was used according to the taxonomy of XML schema languages using the formal language theory that was defined by Murata (Murata et al., 2005). Such formal description has been also used to find out which XML schema language could be used to prepare the schema of the e-learning material markup language as only such schemas are suitable for programs performing validation of XML files. According to Murata the local tree grammar (the grammar of elearning material markup language was identified as local tree grammar) approximately corresponds to DTD schema language. Therefore, the DTD specification of markup language has been created too. So, to find out the structure of e-learning material in the future will be easier as the visual formal descriptions are prepared as well as usual formal descriptions.

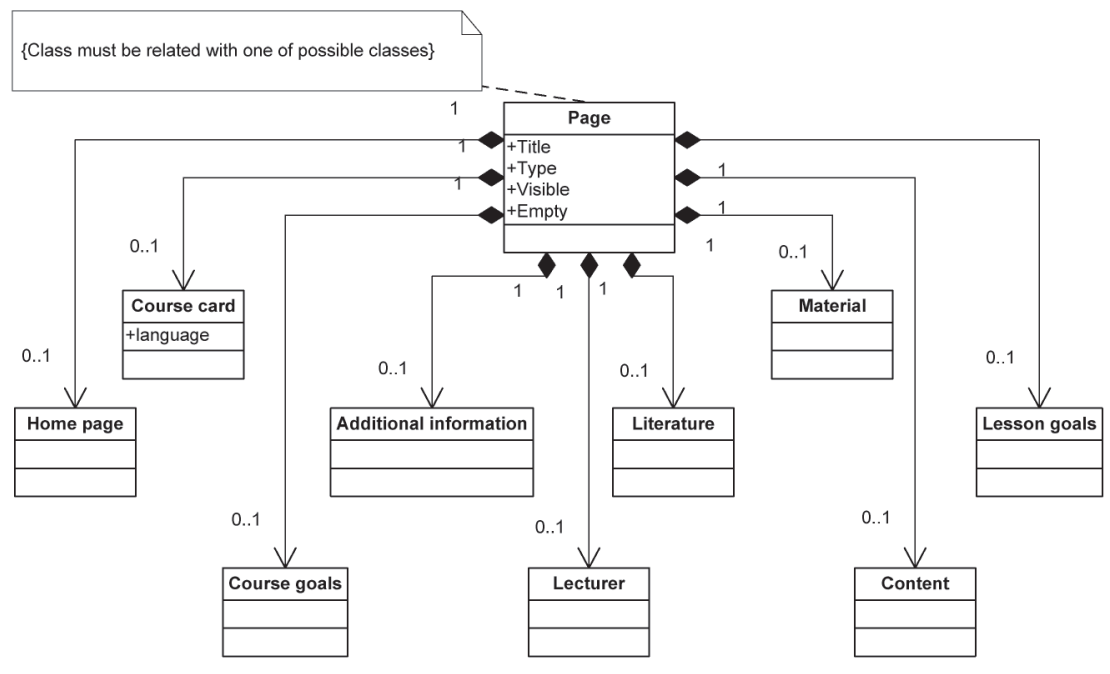

Fig. 2. The model of e-learning material markup language and main data element Page. 


\subsection{Formation of Flexible Learning Objects}

The main feature of the LO is reusability. Therefore, the author rights must be flexible enough that the object could be reused. However, this is not enough and Teege G. sets the two requirements for LO: abstractness and adaptability (Teege, 2002). Abstractness means that object is suitable for different learning contexts and situations automatically, because it is very small - simple. Adaptability means that object may be adapted to the learning contexts and situations. As it was already mentioned, the e-learning material sometimes must be corrected, renewed or adapted before reuse. This means, that requirements for e-learning material format must be applied also for $\mathrm{LO}$, because e-learning material is delivered as LO. If these requirements would be met, the flexibility of LO in regard to reusability would be increased. Thus, the LO could be called as flexible LO. Besides, accordingly to Smith R., FLO is such object that can offer access to the knowledge with different learning methods (Smith, 2004). Therefore, the FLO must be formatted in such a way, that it could be renewed and adapted by changing not only the e-learning material that was delivered as LO, but also changing display rules of e-learning material.

Thus, the formation method of FLO must be based on e-learning material that may be adapted according to the requirements mentioned above. This means that e-learning material should (or could as this is no strict requirement) be described with CourseML language which was described in the previous chapter. E-learning material that is described with CourseML is independent from display rules and may be displayed in different forms. Besides, the information about e-learning material may be also described with CourseML language, though metadata about the object according to any metadata standard (for instance LOM) must be prepared too. The format of e-learning material is the main difference of this method as compared with other common formation methods of LO. The conceptual model of formation method of FLO is given in Fig. 3.

The conceptual model of formation of FLO shows the activities that must be done to form the FLO. According to the model the FLO consists of several components: elearning material, information about e-learning material and display rules of e-learning material. However, when such e-learning material is used together with display template and information which describes the e-learning material, it may be called as e-learning course (eCourse in the diagram). The model of FLO and how e-learning material is used in it is presented in the Fig. 4.

In this model only the FLO structure is presented. However, as it was mentioned earlier the object means content package and its structure definition - manifest. The structure of FLO package and manifest is presented in Fig. 5. Such package is different from the usual LO package, which was presented earlier (Fig. 1). The e-learning material in FLO package is delivered in XML format. The information about e-learning material and content of e-learning material is give in a special documents as well as in manifest as metadata.

In the given structure of FLO package the information about FLO is related to the metadata of FLO. This means that according to the FLO model the information that defines the e-learning material (or eCourse like in the picture), must be transformed into the 


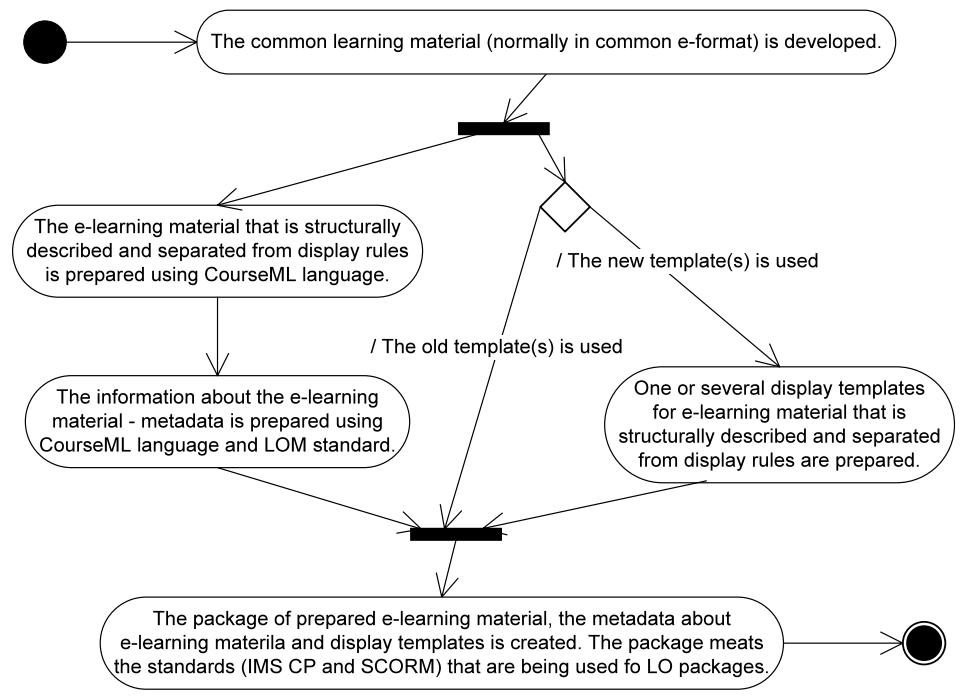

Fig. 3. The conceptual model of formation method of FLO.

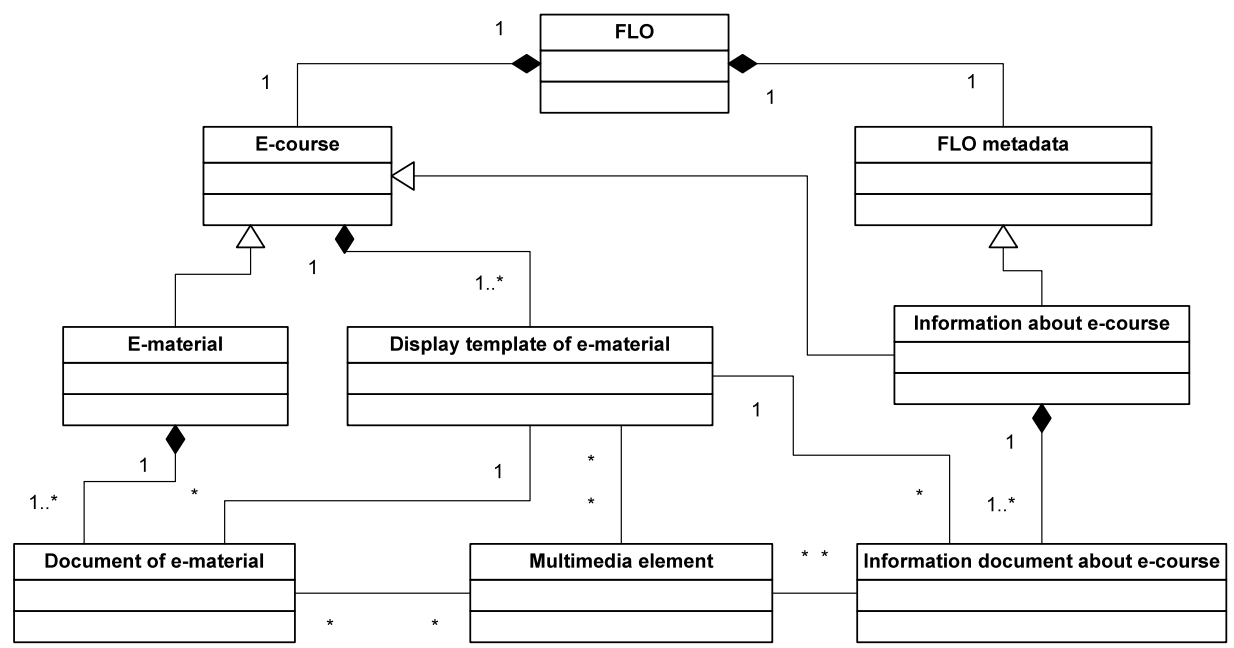

Fig. 4. The conceptual model of FLO.

metadata described by the LOM standard. As the information about e-learning material is kept in XML format documents, the transformation may be done automatically. The algorithm for such transformation is developed using the formal description of appropriate CourseML elements, but is skipped in this article as it is fairly large and may be discussed separately in another article about metadata preparation.

However, metadata is only one part of FLO formation. Another part, which even must be done before the metadata transformation, is formation of e-learning material or the course for LO. The algorithm for this process is presented in the Fig. 6. According to the 


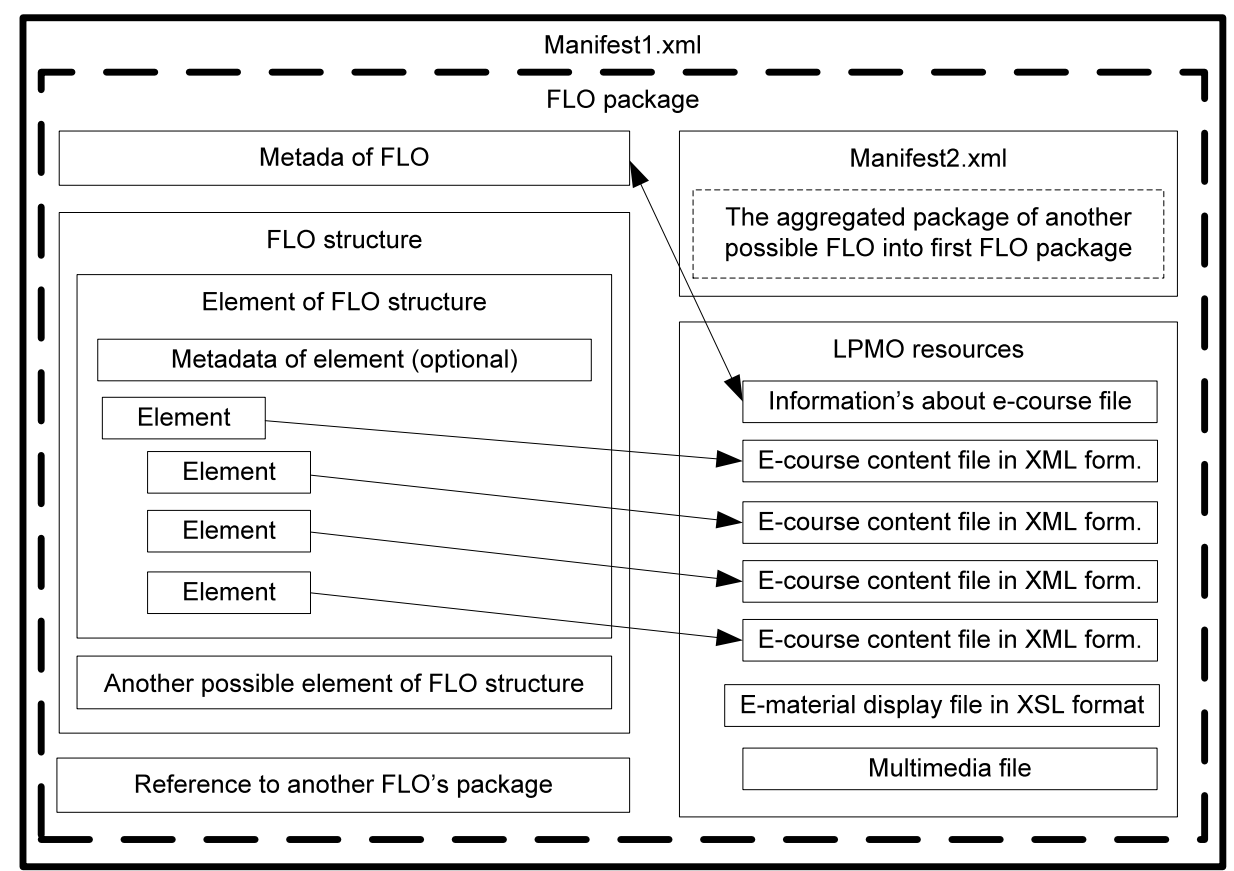

Fig. 5. The structure of FLO package and its manifest.

given algorithm, the e-learning material preparation process may be done manually or may be managed by software tool.

The last part of FLO formation - the FLO package formation algorithm is given in Fig. 7. This algorithm defines manual as well as automatic formation of FLO package with main file in it - manifest.xml. Together with this algorithm must be used metadata formation algorithm in the part of metadata preparation.

The created formation method of FLO enables to adapt the object to the learning context and situation as the content of e-learning material is separated from display rules. This enables to edit material directly in the object or display it in different forms or formats without changing material in initial format and avoiding repeated preparation of material. The FLO may be automatically uploaded into LMS or it may be used separately from LMS. The algorithms show, that many stages of FLO formation may be automated.

\subsection{Practical Value of the Method}

The formation method of FLO enables the flexibility of LO use as well as increases effectiveness of distance learning process for authors, including the university lecturers. The advantage of this method is that FLO, differently from usual LO, holds the learning material separated from display rules. This enables in practice: to adapt the LO for different learning situations (e.g., in learning, where must be used printed material) changing only the display rules for e-learning material that is delivered as this LO, and so avoiding 


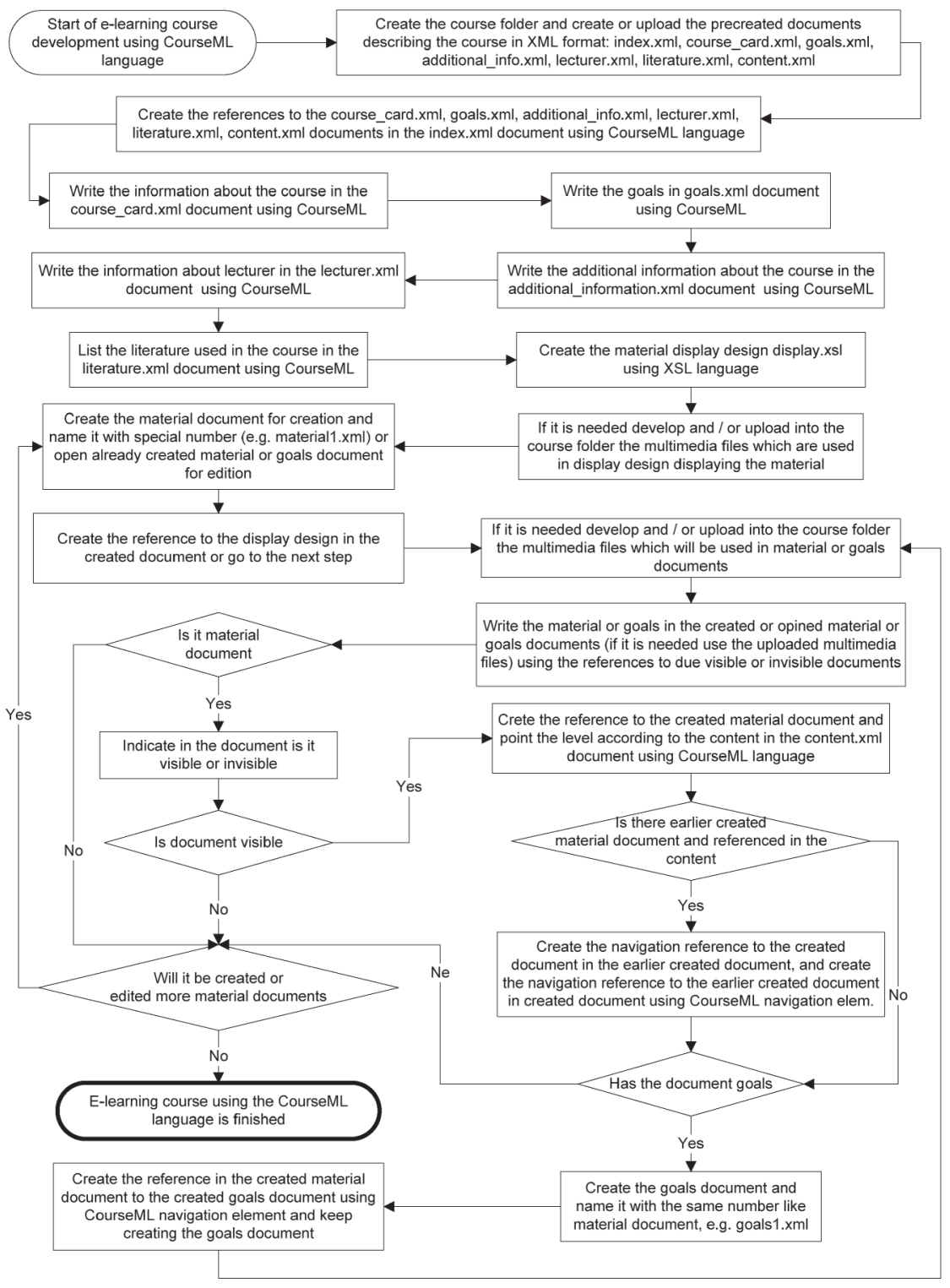

Fig. 6. Formation algorithm of e-learning course for FLO.

the repeated preparation of material and LO; to adapt the LO for individual requirements (e.g., in different learning contexts) directly editing the e-learning material delivered as the LO without use of initial format material, and so avoiding the repeated preparation of material and LO. Besides FLO are smaller than usual LO. The results of LO sizes are given in the Fig. 8. 


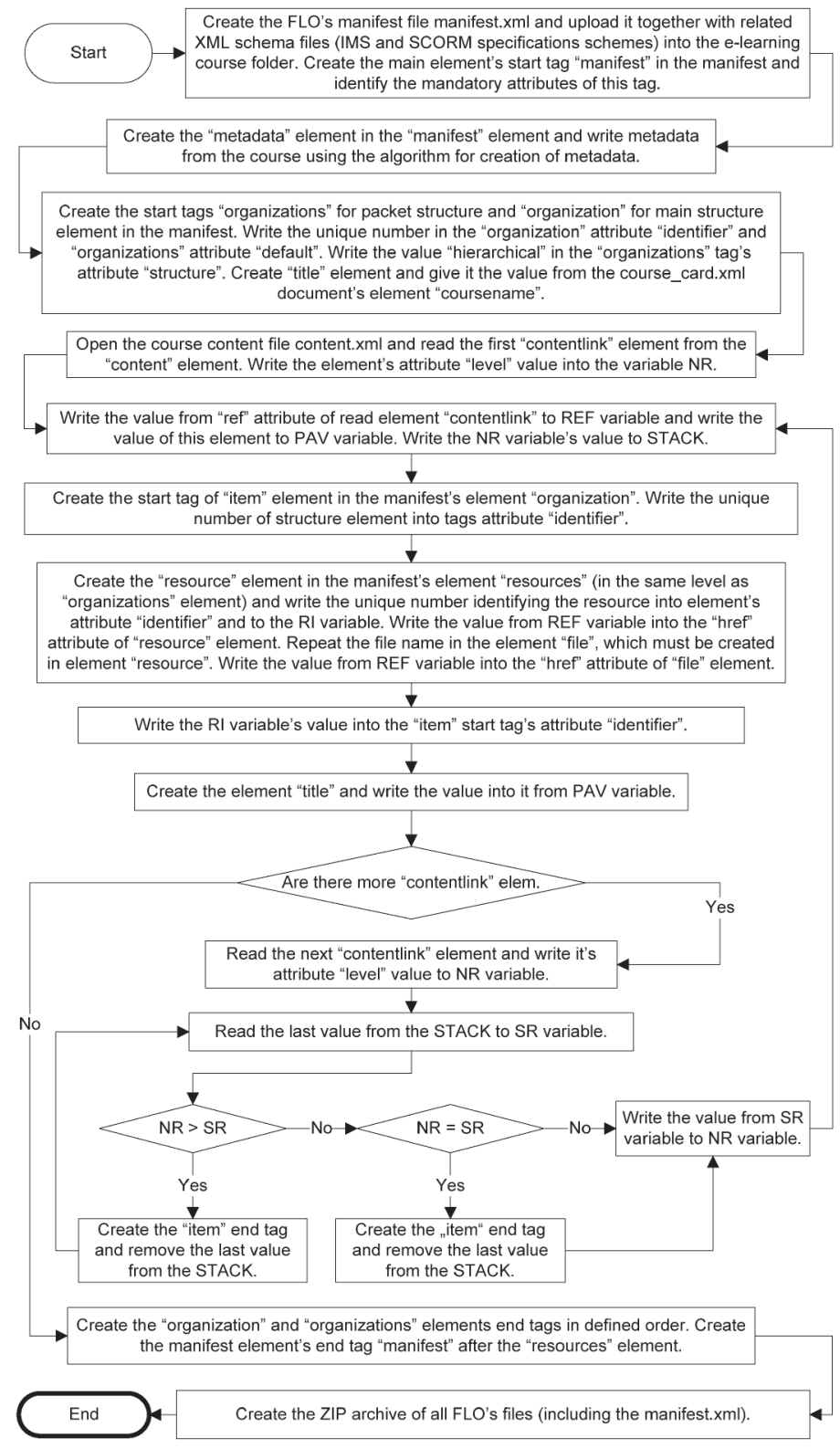

Fig. 7. Formation algorithm of FLO package.

The analysis of LO, when it contains e-learning material in XML and HTML formats, showed that e-learning material in XML format, when it is described with CourseML language, contains less information more than two times. However, the display design in XSL format must be used. Nevertheless, the preparation, edit and display in different formats time input is decreased as the less data must be inserted in the material; the 


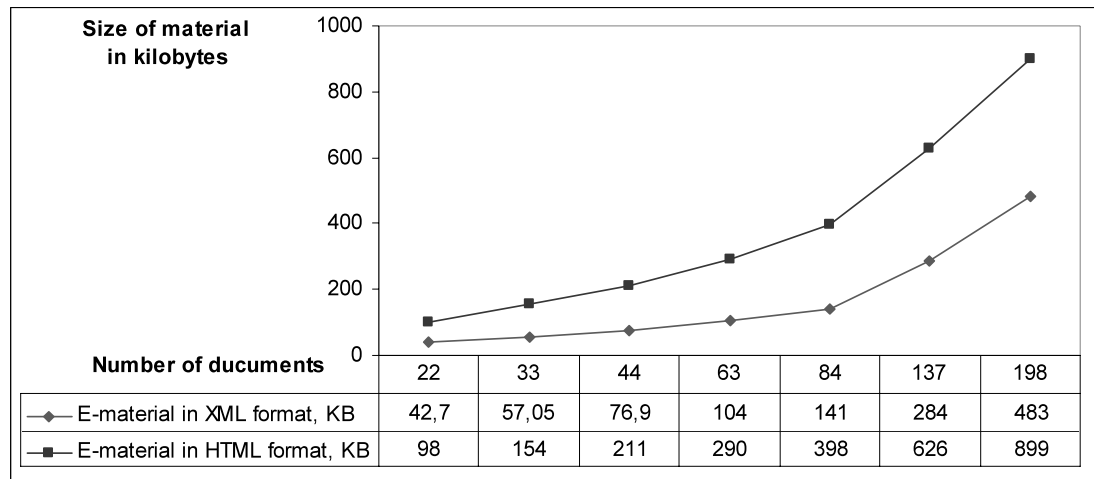

Fig. 8. Comparison of LO with material in XML and HTML formats.

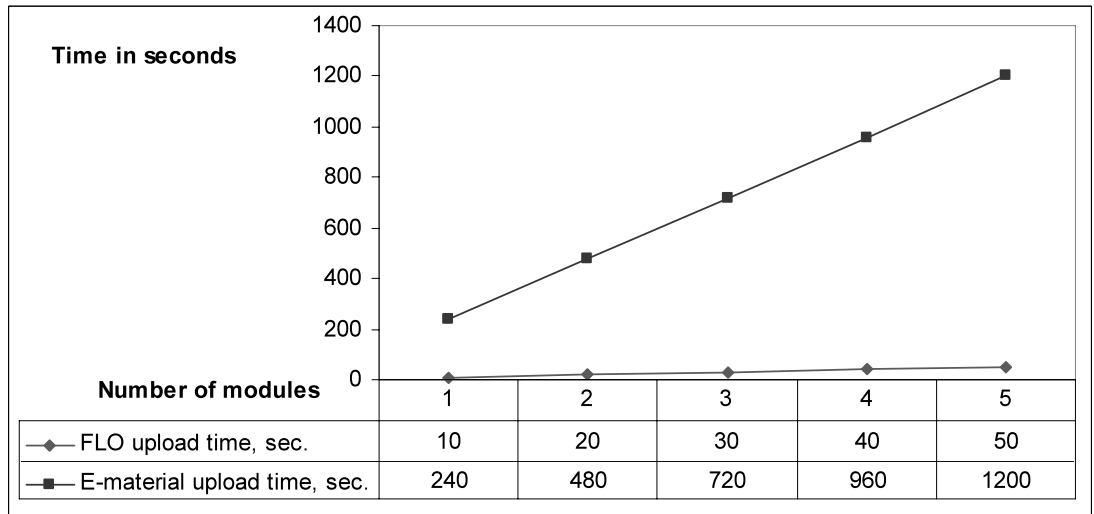

Fig. 9. Comparison of e-learning material upload time into the LMS.

simple commands may be used to insert complex multimedia elements; the documents are more clear and easy to edit; and at last the material may be displayed in different formats directly without any changes when earlier prepared display designs are used.

Moreover, the e-learning material prepared in the LO format may be uploaded into LMS much more effectively than simple e-learning material. The time input analysis showed, that automated process reduced the time more than ten times and made this process more effective. The results are given in the Fig. 9.

The formal description of e-learning material and markup language is used and the formation method of FLO will be implemented in CDK (Course Development Kit) tool. CDK tool was developed at Kaunas University of technology and is used by many lecturers from this and other Lithuanian universities for preparation of e-learning material for distance learning courses. The prepared e-learning material mostly are uploaded into the Blackboard (the LMS which is used in Lithuanian distance education network LieDM) or MOODLE (open source LMS) LMS or are used directly in the internet or compact discs as independent from any system e-learning material. 


\section{Conclusions}

1. At the end of analysis and evaluation of the requirements for e-learning material in distance learning the factors which increase the effectiveness of e-learning material preparation and use in different learning situations have been set:

1.1. for the preparation of e-learning material, the technologies that enable structural description of material and separation from display rules must be used;

1.2. in such a way prepared material must be packed into content packages of LO that corresponds to e-learning standards (IMS CP and SCORM).

2. The prepared formal, but visual description of CourseML language and structure of e-learning material allowed to prepare the algorithms to apply formation method of flexible learning objects. These algorithms allow to describe the metadata and structure of the package. To following the prepared description it is also possible to prepare other algorithms for transformation to other formats or display with different designs e-learning material that is prepared using CourseML language; and to prepare the templates which uses these algorithms. It is necessary on purpose to adapt e-learning material to different learning situations when the different display template or format must be used. Besides, the formal description allowed to find out what XML schema language could be used to prepare CourseML schema. CourseML language was selected according to evaluation criterions of e-learning material that were have been set and analyzed during the analysis of literature.

3. The developed formation method of flexible learning objects decreased the time input:

3.1. to prepare e-learning material, because less data are used in learning material; the same commands of the language are used to insert different format learning resources in learning material; and to display the material in different formats the display templates that were prepared earlier are used;

3.2. to edit e-learning material and increased the flexibility and effectiveness to adapt learning objects, that are used to deliver e-learning material, to learning contexts, because the material may be edited directly with common text editors without using the material in the initial format and bypassing the repeated preparation of material in the final format. It is possible due to increased readableness of documents that are structurally described and separated from display rules;

3.3. to display the learning material in different formats and increased the flexibility and effectiveness to adapt learning objects, that are used to deliver e-learning material, to learning situations, because there came up the possibility to apply automatic material display templates in necessary design and format without using the material in the initial format and bypassing the repeated preparation of material in the final format. It is possible as the material was described structurally and was separated from display rules;

3.4. to upload the learning material to LMS that are compatible with IMS CP or SCORM standards, because the material was delivered as learning object package, while the hierarchical structure of package was described by mentioned e-learning standards. And there came up the possibility to upload material automatically. Though, as the document with content of material was left in the 
package of object, the possibility to use the object not only in LMS, but also separately was saved. Therefore, it was increased the flexibility of using learning object.

4. The formation algorithm of FLO shows that each formation of new object begins from preparation of e-learning material. Whereas, each preparation of such e-learning material begins from common and standard documents which describe the material. Although these documents are simple enough and are described structurally with elearning material markup language, on purpose to accelerate the preparation of material, the standard document templates must be developed and made free of use.

5. The formation method of FLO is based on direct transformation of the e-learning material into the proper form during the view of material. However, there must be developed the fairly complex material display designs in the XSL format. Therefore, on purpose to ensure the use of the method for any material developer, who is not even the specialist of information technologies, must be developed various material display designs and made free of use.

6. The formation algorithm of FLO shows that it is fairly simple process. However, some parts of this algorithm (the formation of metadata and the formation of object's content package algorithms) shows that this process may be automated and in such a way the formation of FLO may be accelerated decreasing the time of formation of LO and the work time input. Besides, on purpose to increase more the effectiveness of the formation of FLO and to facilitate more the formation process for specialists not from information technologies domain, the formation tool or system for formation of such objects must be developed.

\section{References}

Anderson, T. and Elloumi, F. (2004). Theory and Practice of Online Learning. Athabasca University.

Bareiša, E., Karčiauskas, E. and Blažauskas, T. (2005). Development of case tools for software process improvement. Information Technology and Control, 34(2A), 181-187.

Blažauskas, T., Keršienè, V. and Sekliuckis, V. (2005). Elektroninio mokymosi išteklių nuolatinès plètros modelis. Informacijos mokslai, 35, 94-104 (in Lithuanian).

Carbonara, D. (2005). Technology Literacy Applications in Learning Environments. Information Science Publishing.

Dietinger, T. (2003). Aspects of E-Learning Environments: Thesis, Technical Science. Graz University of Technology, Graz, Austria. http: / /www. iicm.tugraz.at/thesis/tdieting_diss.doc

Downes, S. (2000). Learning Objects. University of Alberta.

Fisler, J., and Bleisch, S. (2006). ELML, the E-lesson markup language - developing sustainable e-learning content using an open source XML framework. In WEBIST 2006, Portugal, April 11-13, 2006. INSTICC Press.

Horton, W. and Horton, K. (2003). E-Learning Tools and Technologies. Wiley Publishing, Inc.

Howard, C., Schenk, K. and Discenza, R. (2003). Distance Learning and University Effectiveness. Information Science Publishing.

Kubiliūnas, R., Genutis, M. and Cibulskis, G. (2002). Course development KIT - a new tool to create e-learning courses. In Lifelong Learning - a Challenge for All: Proceedings of the International Conference, Riga, Latvia, 8-9 November, 2002.

Mishra, S. and Sharma, C.R. (2005). Interactive Multimedia in Education and Training. Idea Group Publishing. Moore, M.G. and Anderson, W.G. (2003). Handbook of Distance Education. Lawrence Erlbaum Associates. 
Morrison, D. (2003). E-Learning Strategies. John Wiley \& Sons Ltd.

Murata, M., Lee, D. and Mani, M. (2005). Taxonomy of XML schema languages using formal language theory. ACM Transactions on Internet Technology (TOIT), 5(4), 660-704.

Piskurich, G.M. (2004). Getting the Most from Online Learning. Pfeiffer.

Smith, R. (2004). Guidelines For Authors of Learning Objects. Learning Objects Initiative.

Štuikys, V. and Damaševičius, R. (2008). Development of generative learning objects using feature diagrams and generative techniques. Informatics in Education, 7(2), 277-288.

Targamadzè, A., Balbieris, G. and Kubiliūnas, R. (2005). The new generation of virtual learning environments in Lithuania. Informacinés technologijos ir valdymas, 34(3), 276-284 (in Lithuanian).

Teege, G. (2002). Reuse of teaching materials in targeteam. In International Workshop on Interactive Computer Aided Learning ICL 2002.

Tomey, L.A. (2008). Encyclopedia of Information Technology Curriculum Integration. Information Science Reference.

R. Kubiliūnas has graduated from Kaunas University of Technology and finished doctoral studies in informatics of engineering (2007). Now he is junior scientific employee at Research Laboratory of Distance Learning Technologies, Department of Multimedia Engineering, Kaunas University of Technology, Lithuania. His research interests include distance learning standards, markup languages for learning content development, development of learning objects and related software, learning management systems and environments.

E. Bareiša obtained $\mathrm{PhD}$ degree from Kaunas Politechnical Institute in 1987. Currently he is in position of head and professor at Software Engineering Department, Kaunas University of Technology, Lithuania. His research interests include high-level synthesis and VLSI test generation. 


\section{Lanksčiai pritaikomu mokymosi objektu formavimo metodas}

Ramūnas KUBILIŪNAS, Eduardas BAREIŠA

Šiame straipsnyje yra pateikta trumpa lanksčiai pritaikomu mokymosi objektu formavimo metodo apžvalga. Šio metodo pagrindas yra struktūriškai aprašyta ir nuo atvaizdavimo taisykliu atskirta el. mokymosi medžiaga. Mokymosi objektai, kuriais pateikiama tokia medžiaga, gali būti pritaikyti pagal individualius poreikius ir gali būti panaudoti skirtinguose mokymosi kontekstuose nekeičiant el. mokymosi medžiagos. Norint pakeisti tokio mokymosi objekto medžiagos pateikimo formą, užtenka pakeisti medžiagos atvaizdavimo taisykles. Tačiau, jei el. mokymosi medžiaga taip pat turi būti pritaikyta, tai padaryti yra kur kas lengviau, nes medžiaga yra struktūriškai aprašyta ir turi mažiau techninès atvaizdavimo informacijos. Tokių mokymosi objektu pritaikymas yra veiksmingesnis ir reikalauja mažiau laiko sąnaudų, todèl jie yra vadinami lanksčiai pritaikomais mokymosi objektais. 